\title{
Microbial Status and Quality Assessment of Complementary Food Produced From Co-Fermentation of Sorghum and Pumpkin Seed Fortified with Carrot
}

\author{
Uchegbu Nneka N*, Onwurafor Eucharia U, Nwadi, Oluchukwu MM
}

Department of Food Science and Technology University of Nigeria, Nsukka, Nigeria

\author{
DOI: $10.36348 /$ SJPM.2019.v04i12.003 \\ | Received: 30.11 .2019 | Accepted: 07.12.2019 | Published: 11.12 .2019 \\ *Corresponding author: Uchegbu Nneka N
}

\section{Abstract}

The aim of this study was to formulate and evaluate the chemical, functional, microbial and sensory attributes of complementary food from blends of sorghum, pumpkin seed and carrot. Sorghum and pumpkin seeds in the ratio of $70: 30$ (A), 60:40 (B), respectively were co-fermented aerobically for 24,48 , and $72 \mathrm{~h}$ at room temperature $\left(30{ }^{\circ} \mathrm{C}\right)$. In the same ratio as samples (A) and (B), control (C) and (D) were unfermented. Carrots (20\% W/W) was added to all the samples. The samples were subjected to chemical, anti-nutritional, functional, microbial and organoleptic properties using standard methods. The protein content of the fermented samples was higher than that of the unfermented samples. Tannins and phytates decreased after fermentation. Microbial counts decreased as fermentation progressed to $72 \mathrm{~h}$. Water and oil absorption capacity, solubility index, bulk density and least gelation concentration were within the acceptable ranges for complementary food. Leucine and Lysine contents were high in all the samples. Histidine, isoleucine and methionine were higher in co-fermented samples than unfermented samples. The carotenoid value in co-fermented mixture was comparable to recommended daily allowance (RDA) for complementary food value for 10-20 months infants. Organoleptically, co-fermented samples scored higher in general acceptability, and unfermented samples scored higher than the co-fermented in terms of colour, aroma and taste. It could be concluded that co-fermented sorghum, pumpkin seed fortified with carrot blend diet had a better nutritional quality than the unfermented counterparts based on the overall findings.

Keywords: Co-fermentation, complementary food, undernourished, infants, sorghum, pumpkin seed.

Copyright @ 2019: This is an open-access article distributed under the terms of the Creative Commons Attribution license which permits unrestricted
use, distribution, and reproduction in any medium for non-commercial use (NonCommercial, or CC-BY-NC) provided the original author and sources
are credited.

\section{INTRODUCTION}

Child undernutrition increases the risk of neonatal, child mortality, morbidities and future maternal reproductive outcomes [1, 2]. It is responsible for $45 \%$ death rate in children below the age of five. Undernutrition has resulted to the death of two million children below the age of five annually around the world, especially in Africa where one-third of all undernourished children globally reside [3, 1]. The predominance of stunting remains one of the major public health problems, and a major population distribution suffer due to severe or moderate undernutrition at early stage of life (childhood), mostly in developing countries. Over a 10 year period (1990 2010), the only region with increased number of stunted children below five years is in Africa. Projection towards 2025 reveals that increase in population of stunted children is likely to persist if not controlled [1]. Poor feeding practices where complementary foods insufficient in macro and micronutrients are given to infants at risk has been the major reason of stunting in children. As infants grow and become more active within the first six months of life, breast milk alone does not provide the nutritional requirements and the gap keeps expanding as the child grows [4, 5]. Complementary foods help critically in bridging the nutritional gaps. Complementary foods are foods other than breast milk or infant formula (liquids, semisolids, and solids) introduced to an infant to provide nutrients.

Complementary foods, therefore, must be adequate to satisfy the nutritional needs of the growing child together with breastfeeding. Most low-income households cannot afford expensive commercial food products and therefore, rely mainly on home-made starchy cereal porridges. The most important consideration in complementary food formulation is to ascertain whether the food have ease of preparation, affordable price and achieve the desired overall energy and nutrient densities for the infant [6]. The most 
commonly used traditional prepared complementary foods are cereal porridges which are mainly starchy pastes but protein and vitamin A activity of these foods in form of provitamin (B-carotene) is low [7], which result to poor nutrition values characterized by low energy, high bulk and low nutrient densities [8]. This scenario contributes to the high occurrence of child under-nutrition below the age of five $[9,10]$. Therefore, traditional complementary food could be improved by enriching cereal-based food with other protein and vitamin source such as legumes and vegetables which will meet the nutritional demands of infant of weaning age (6-18 months).

Sorghum is well-known to have chiefly yielded to food security in both semi-arid and tropical regions because of its tolerance to tough, drought environment, minimal growth time together with pests and diseases resistance [11] Nigeria is the third largest world producer after the United States and India, and the largest producer of sorghum in West Africa [12]. Utilization of sorghum in complementary foods has been reported $[13,14]$. Sorghum is an essential staple crop in most African regions particularly, Nigeria [15]. It contains about $9 \%$ protein which enables humans to survive in times of famine [15]. Similar to many cereals, it is important to blend them with legume to enhance their nutritional quality.

During the last decades, demand of underutilized vegetable by-products by the food industry and the population has been on the increase. The byproducts and its application adds value to the production section, boosts food security, as well as aids the formulation of new food products and reduction of waste [16]. An increase in industrial production of sliced, packaged as well as commercialized pumpkin has been perceived to generate huge waste such as stalks, shells and mostly seeds. Pumpkin seed (Cucurbite pepo) is considered recently because of health-protective values of its seeds aside its nutritional content. It has abundant protein as well as pharmacological properties against diabetics, fungal and bacterial infection, inflammation and antioxidant benefit [17]. Aside its nutrient-dense nature, its seed flour, when used to fortify complementary food mix, is friendly [18].

Vitamin A Deficiency is predominant in preschool children in Africa, is caused by the presence of low serum levels of vitamin A and when the plasma retinol concentrations is less than $<0,70 \mathrm{mmol}^{-1}$ [19]. Carrot is a root vegetable that is distributed worldwide and belongs to the family Apiaceae. It is rich in antioxidant, and an excellent vegetable source of provitamin A (beta carotene) form which when metabolized is converted to Vitamin A in the liver [20, 21]. It provides protection against heart disease, stroke and in the building of strong bones and healthy nervous systems [4] and also promotes good vision mostly at night.

The micro and macronutrient deficiencies of complementary food could be responsible for certain growth and development disorder; this is why nutritional adequate complementary foods from locally available food crops are necessary. In this study, traditional co-fermentation of sorghum, pumpkin seed fortified with carrot might be a strong way to improve the health of infants at low cost. Therefore, the objective of this study was to formulate and evaluate the chemical, functional, microbial and sensory attributes of complementary food from blend of sorghum, pumpkin seed and carrot.

\section{MATERIALS AND METHODS Materials}

Sorghum and carrot were bought from a local market in Enugu state, Nigeria. Dehulled pumpkin seed kernels were purchased from Grain Mill Firm in Enugu City, Nigeria. Analytical grade of chemicals were used.

\section{Methods \\ Sample preparation}

Sorghum seeds were sorted, washed, milled, and sieved using a 60 mesh wire screen size. Using the method of Simwaka et al. [22], first, the pumpkin seed kernels were dehulled, milled, and sieved using a 100 mesh wire screen size, $n$-hexane was used at the ratio of 1:4 (w/v) with pumpkin seed flour for de-fattening. The slurry was agitated for $8 \mathrm{~h}$ and filtered. The defatted pumpkin seed flour was dried in a Gallenkamp oven (BS model OV 160, Manchester, UK) to evaporate the remaining solvent, milled again, and sieved using 60 mesh wire screen size. The fresh carrot samples were thoroughly cleaned and pericarp removed. For the carrot flour, $4 \mathrm{~kg}$ of the carrot were grated, dried at $50^{\circ} \mathrm{C}$ for $8 \mathrm{~h}$ and hammer milled. The derived flours were packed in polyethene bag and stored at refrigeration temperature $\left(4^{\circ} \mathrm{C}\right)$ until used.

\section{Formulation of Complementary food sample from sorghum, pumpkin seed and Carrot}

One part of each sorghum and pumpkin seed flour was divided into portions, one portion each of sorghum and pumpkin seed flour was blended in the ratio of 70:30 respectively (A) and 60:40, respectively (B) and they were co-fermented for $24,48,72 h$. In the same ratio as the co-fermented samples, the other parts which served as control (C) and (D) were unfermented. Carrot $(20 \% \mathrm{~W} / \mathrm{W})$ was added to all the samples. A total of eight samples were formulated as follows:

Co-fermented sorghum and pumpkin seed (70:30) with carrot $(20 \% W / W)$ for $24 h=($ CA 24).

Co-fermented sorghum and pumpkin seed (70:30) with carrot $(20 \% W / W)$ for $48 h=(\mathrm{CA} 48)$.

Co-fermented sorghum and pumpkin seed (70:30) with carrot $(20 \% \mathrm{~W} / \mathrm{W})$ for $72 h=(\mathrm{CA} 72)$ 
Co-fermented sorghum and pumpkin seed (60:40) with carrot $(20 \% W / W)$ for $24 h=($ CB 24)

Co-fermented sorghum and pumpkin seed (60:40) with carrot $(20 \% W / W)$ for $48 h=(\mathrm{CB} 48)$

Co-fermented sorghum and pumpkin seed (60:40) with carrot $(20 \% \mathrm{~W} / W)$ for $72 h=(\mathrm{CB} 72)$

Unfermented sorghum and pumpkin seed (70:30) with carrot $(20 \% W / W)=(\mathrm{UC})$

Unfermented sorghum and pumpkin seed (60:40) with carrot $(20 \% \mathrm{~W} / \mathrm{W})=(\mathrm{UD})$

\section{Fermentation}

Using the method of Usha and Chandra [23], part of each mixture was co-fermented through natural fermentation by adding $200 \mathrm{ml}$ of distilled water and left to ferment for $24 h, 48 h$ and $72 h$ at $30^{\circ} C$. At every $24 h$ of fermentation time, microbial status was evaluated. The slurry was agitated, oven-dried (hot air oven) at $65^{\circ} \mathrm{C}$ for $17 \mathrm{~h}$ and milled into flour, sieved to pass through a 60 mesh wire screen and stored at $4{ }^{\circ} \mathrm{C}$ until analysis.

\section{Determination of Proximate Analysis}

The determination of proximate composition of co-fermented and unfermented composite flours were thus: Moisture, fat and ash contents of the samples were by AOAC [24] method. The Crude protein was analysed using micro-Kjeldahl method which involves conversion factor of $N \times 6.25$. Finally, Carbohydrate determination was carried out by differential method [25].

\section{Determination of Amino Acid Profile}

The Amino acid level of co-fermented and unfermented composite flours was analysed using AOAC method [26]. Technicon Sequential Multisample (TSM) Amino Acid Analyzer, (Technicon Instruments Corporation, New York) which is principled on ionexchange chromatography (IEC) was used. It separates acidic, basic and neutral acids of the hydrolysate. The samples were dried until a constant weight of the sample was derived. The sample were defatted, hydrolysed, filtered to remove the humins and evaporated to dryness at $40{ }^{\circ} \mathrm{C}$ under vacuum using a rotary evaporator. Each residue was dissolved in $5 \mathrm{ml}$ of acetate buffer ( $\mathrm{pH}$ 2.0) and stored in a plastic specimen bottle, kept inside the deep freezer for subsequent analysis. Each sample $(5 \mu l)$ was weighed into the analyzer for 76 minutes with column flow rate of $0.50 \mathrm{ml} / \mathrm{min}$ at $60{ }^{\circ} \mathrm{C}$ and reproducibility consistent within $3 \%$. Amino acid represented was calculated using net height peak of chart record of the TSM for each.

\section{Determination of Functional properties}

Bulk density was determined as described by Anderson et al. [27] while Least gelation concentration was analyzed using the method of Sathe et al. [28]. Water and oil absorption capacity of the samples was determined using the method of Sathe et al. [28]. The solubility of the samples was analysed according to Leach et al. [29].

\section{Determination of Anti-Nutritional property}

Tannin determination of the samples was done as described by Price et al. [30] while the modified Haug and Lantzsch method [31] described by Onyango et al. [32] was used for phytate determination.

\section{Determination of Carotenoid}

Carotenoid determination was done using Rodriguez-Amaya and Kimura method [33]. For extraction, cold acetone, pestle and mortar were used and later subjected to petroleum ether. Absorbance rate was taken at $450 \mathrm{~nm}$.

\section{Calculation}

Total carotenoid content $(\mu g / 100 g)=\mathrm{A} \times$ Volume $(m l) \times$ $104 \times 100$

$\mathrm{A}^{1 \%} 1 \mathrm{~cm} \mathrm{x}$ weight of sample $(\mathrm{g})$

Total Carotenoid content $(\mu g / 100) / 6=\mu g$ RE/100g

Where: $\mathrm{A}=$ absorbance, Volume $=50 \mathrm{ml} \mathrm{A}$ $1 \mathrm{~cm}=$ Absorbance co-efficient of $\beta$-carotene in

PE (2592)

\section{Microbiological Evaluations}

$10 \mathrm{~mm}$ steep liquor was aseptically taken every $24 h$ over a $72 h$ period and diluted serially; using different sterile $1.0 \mathrm{ml}$ pipette $0.1 \mathrm{ml}$ of $10-1$ to $10-8$ dilutions. Each sample has 10 serial dilutions. For lactic acid bacteria isolation, the samples were plated by mixing with MRS agar medium in McCartney bottles and neatly poured into sterile petri dishes. The petri dishes were incubated in anaerobic jars using bilateral tubal ligation (BTL) Gas Park (hydrogen and carbon dioxide generators) after solidifying. The study of the colonial morphology and cellular characteristic for the various colonies obtained were carried out. For the samples, plate count agar (PCA) was used for total viable count (TVC). Malt extract agar (MEA) containing $100 \mathrm{ml}$ were used for yeasts and mould counts while streptomycin and MacConkey agar were used for Enterobacteriaceae. Plates were incubated at $37{ }^{\circ} C$ for $24 h$. For the PCA $30{ }^{\circ} C$, for $48 h$ for MRS, $37^{\circ} \mathrm{C}$ for $24 h$ for MacConkey and 4 days for the MEA medium. The plates were observed for bacterial growth after incubation and the colonies were selected randomly. Cultures were sub-cultured repeatedly and for a pure culture to be obtained, streaking was done on sterile De Man, Rogosa and Sharpe (MRS) plates.

\section{Characterization of Isolates}

The characterization of the isolated microorganisms was carried out using macroscopic and biochemical analysis. For identification purposes, Pure growth was inoculated heavily into modified MRS broth containing the following sugar: glucose (plus Durham's tube) lactose, sucrose, salicin, mannitol, sorbose and xylose in MRS broth containing $2 \%$ glucose and in which the ammonium citrate has been 
replaced by $0.3 \%$ arginine for arginine hydrolysis, and in MRS broth containing $4 \%$ sodium chloride. Incubation was carried out at $28{ }^{\circ} \mathrm{C}-30{ }^{\circ} \mathrm{C}$ for 4 days. Also, inoculated tubes of MRS broth were incubated at $15^{\circ} \mathrm{C}$ and $45^{\circ} \mathrm{C}$. Identification according to Oyarekua [34] was carried out.

\section{Sensory evaluation}

Sensory evaluation was done using thirteen (13) mothers from a local crèche. A 9-point Hedonic scales (1- dislike extremely, 5- neither like nor dislike, 9- like extremely) as described by Ihekoronye and Ngoddy [35] was used to assess the sensory attributes of taste, consistency, appearance, Aroma, and overall acceptability. Respondents were made to abstain from tasting anything an hour prior to the evaluation. Two spoonfuls of boiled gruel of the eight samples were dished into a transparent plate so as not to affect the appearance scoring of the gruels. Each mother was provided with a spoon, serviette paper, and cup of water to rinse their mouths to prevent the taste of one gruel from affecting the other. Sensory evaluation form was provided for each respondent.

\section{STATISTICAL ANALYSIS}

Data generated from the study were evaluated by Analysis of Variance (ANOVA) at 5\% level of significance. Means were separated by Duncan New Multiple Range Test using SPSS version 20 software. The non-parametric Friedman test and 2-sample t-test were employed in determining the statistical differences among the product sensory attributes.

\section{RESULTS AND DISCUSSION \\ Effect of fermentation on the proximate composition of complementary foods blends from sorghum, pumpkin seed and carrot flour}

The result of protein content presented in Table 1 revealed that proteins present in the blends were significantly $(\mathrm{p}<0.05)$ increased by increasing the fermentation time. Protein content of samples ranged from $16.00-17.10 \%$ in fermented samples and 12.11 to $12.69 \%$ in unfermented samples. The protein values for fermented samples conforms to $\mathrm{FAO} / \mathrm{WHO}$ recommended values of $>15 \%$ [36]. A similar observation was reported by Simwake et al. [22] where protein content continued to increase up to $30 h$ of fermentation and similar observation was also reported by Pranoto [37]. Utilization of carbohydrates by microorganisms for energy purposes during fermentation leads to concentration of nitrogen content which is an index of protein content in foods [32].

Table-1: Proximate composition (\%) of complementary food from blends of sorghum, pumpkin seed and carrot flour

\begin{tabular}{|l|l|l|l|l|l|l|}
\hline & Crude protein & Ash & Moisture content & Fat & Fiber & Carbohydrate \\
\hline CA24 & $16.00^{\mathrm{c}} \pm 2.01$ & $1.80^{\mathrm{d}} \pm 0.08$ & $7.19^{\mathrm{c}} \pm 4.71$ & $5.01^{\mathrm{f}} \pm 5.01$ & $1.81^{\mathrm{d}} \pm 0.00$ & $68.19^{\mathrm{c}} \pm 4.34$ \\
\hline CA48 & $16.77^{\mathrm{b}} \pm 2.00$ & $1.61^{\mathrm{e}} \pm 0.06$ & $7.21^{\mathrm{c}} \pm 0.14$ & $5.03^{\mathrm{f}} \pm 1.71$ & $1.70^{\mathrm{e}} \pm 0.01$ & $67.68^{\mathrm{d}} \pm 3.00$ \\
\hline CA72 & $17.10^{\mathrm{a}} \pm 1.17$ & $1.91^{\mathrm{c}} \pm 1.11$ & $8.08^{\mathrm{a}} \pm 0.25$ & $5.00^{\mathrm{f}} \pm 1.02$ & $1.81^{\mathrm{d}} \pm$ & $66.10^{\mathrm{g}} \pm 0.23$ \\
\hline CB24 & $16.11^{\mathrm{c}} \pm 3.41$ & $2.00^{\mathrm{c}} \pm 1.24$ & $7.11^{\mathrm{d}} \pm 4.42$ & $6.21^{\mathrm{b}} \pm 0.00$ & $1.44^{\mathrm{f}} \pm 1.01$ & $67.13^{\mathrm{f}} \pm 1.11$ \\
\hline CB48 & $16.25^{\mathrm{d}} \pm 5.11$ & $1.91^{\mathrm{c}} \pm 0.34$ & $7.01^{\mathrm{e}} \pm 0.55$ & $6.11^{\mathrm{c}} \pm 3.04$ & $1.40^{\mathrm{f}} \pm 2.11$ & $67.32^{\mathrm{e}} \pm 2.56$ \\
\hline CB72 & $16.26^{\mathrm{d}} \pm 0.33$ & $1.84^{\mathrm{d}} \pm 4.11$ & $7.82^{\mathrm{b}} \pm 3.02$ & $5.85^{\mathrm{e}} \pm 3.11$ & $1.31^{\mathrm{g}} \pm 2.05 c$ & $66.92^{\mathrm{d}} \pm 3.72$ \\
\hline UC & $12.11^{\mathrm{e}} \pm 1.37$ & $2.71^{\mathrm{b}} \pm 2.05$ & $6.05^{\mathrm{g}} \pm 2.71$ & $6.00^{\mathrm{d}} \pm 2.44$ & $2.40^{\mathrm{a}} \pm 3.41$ & $70.73^{\mathrm{a}} \pm 2.56$ \\
\hline UD & $12.69^{\mathrm{f}} \pm 4.14$ & $2.89^{\mathrm{a}} \pm 2.54$ & $6.21^{\mathrm{f}} \pm 1.15$ & $6.33^{\mathrm{a}} \pm 0.02$ & $2.11^{\mathrm{b}} \pm 0.51$ & $69.77^{\mathrm{b}} \pm 0.17$ \\
\hline
\end{tabular}

Values with different superscript letters within the same column are significantly different $(\mathrm{p}<0.05$, mean $\pm S D, n=3)$

The ash contents ranged from $1.61-2.00 \%$ in fermented samples and $2.71-2.89 \%$ in unfermented samples. It was observed that the ash content significantly $(\mathrm{P}<0.05)$ decreased after fermentation. This decrease in ash content of the flour can be related to soluble mineral elements of the flour samples leaching into fermenting medium.

Moisture content decreased significantly $(\mathrm{p}<0.05)$ as fermentation time increases with the values ranging from 6.05 to $8.08 \%$ after fermentation for 72 $h$, which results to significant $(\mathrm{p}<0.05)$ differences in all the samples moisture content. However, the moisture content of all the flour samples were within normal range for dried flour blends, that was below $12.5 \%$ for shelf-stable storage [38] which confers a long shelf-life as desired and conformity to standard.
The carbohydrate content of the fermented flour blends was lower than those of unfermented blends, with the fermented flour blends ranging from 66.1 to $68.19 \%$, and that of unfermented blends were 69.77 and $70.73 \%$ UC and UD respectively. The experimental results of the flour blends before and after fermentation $(66.10$ and $70.73 \%)$ were similar to research findings by Mbata et al. [39] on fermented maize flour and Bambara groundnut-maize fortified flour. Reduction in carbohydrate level of fermented samples can be related to the activities of microorganism in quest for energy.

The result of fat content showed that fermented blends had lower fat ranging from $5.00-$ $6.21 \%$, compared to that of unfermented blends which 6.00 and $6.33 \%$ for UC and UD, respectively. This was similar to the work carried out by Afify et al. [40] who reported reduction in fat content of three (3) white 
varieties of sorghum after fermentation. Enzymatic activities involved in physiological and biochemical changes occurring during fermentation might be responsible for the reduction in fat.

Effect of fermentation on the antinutrient composition of complementary foods blends from sorghum, pumpkin seed and carrot flour

The tannin content was presented in Table 2 . The tannin contents ranged from 0.92 to $1.05 \mathrm{mg} / \mathrm{ml}$ in both fermented and unfermented flour blends. Fermentation reduced the tannin content of the flour blends. The tannin content of co-fermented samples showed significant $(\mathrm{P}<0.5)$ decrease as fermentation progressed. This corresponds with the result derived by Obizoba and Amaechi [41] and [42]. The decreases could be attributed to the effect of fermentation on polyphenolic compounds or tannin complexes which brings about hydrolysis of the antinutrient [43]. Also, Obizoba and Atii [44] reported the libration of nutrients during fermentation through the breakdown of tanninprotein, tannin acid-starch and tannin-iron complexes. It is well known that tannin bind proteins, carbohydrates and minerals, thereby reduces their bioavailability but fermentation liberates these food components from binding agents as well as makes them bioavailable.

Table-2: Antinutrient composition of complementary food from blends of sorghum, pumpkin seed and carrot flour

\begin{tabular}{|l|l|l|}
\hline & Tannin $(\mathbf{m g} / \mathbf{m l})$ & Phytate $(\mathbf{g} / \mathbf{1 0 0 g})$ \\
\hline CA 24 & $1.01^{\mathrm{c}} \pm 2.01$ & $1.07^{\mathrm{d}} \pm 0.00$ \\
\hline CA 48 & $0.97^{\mathrm{d}} \pm 3.24$ & $0.99^{\mathrm{e}} \pm 3.01$ \\
\hline CA 72 & $0.91^{\mathrm{e}} \pm 1.00$ & $0.81^{\mathrm{f}} \pm 0.11$ \\
\hline CB 24 & $1.00^{\mathrm{c}} \pm 0.00$ & $1.24^{\mathrm{c}} \pm 2.11$ \\
\hline CB 48 & $0.98^{\mathrm{d}} \pm 1.51$ & $0.87^{\mathrm{f}} \pm 5.02$ \\
\hline CB 72 & $0.92^{\mathrm{e}} \pm 0.01$ & $0.91^{\mathrm{e}} \pm 0.34$ \\
\hline UC & $1.05^{\mathrm{b}} \pm 0.13$ & $1.98^{\mathrm{a}} \pm 1.22$ \\
\hline UD & $1.00^{\mathrm{a}} \pm 2.37$ & $1.81^{\mathrm{b}} \pm 0.19$ \\
\hline
\end{tabular}

Values with different superscript letters within the same column are significantly different $(\mathrm{p}<0.05$, mean $\pm S D, n=3)$

The unfermented samples had higher contents of phytates than fermented samples with UC having the highest value $(1.98 \mathrm{~g} / 100 \mathrm{~g})$ and CA 72 having the lowest value $(0.81 \mathrm{~g} / 100 \mathrm{~g})$. The combination that had the higher quantity of pumpkin gave a higher value of phytate. Antinutrients are naturally proteinous and pumpkin flour is rich in protein content [22].

According to Adeyemo and Onilude [45], most cereals and legumes contain some appreciable amounts of phytate, tannins, trypsin inhibitors and other antinutrients which may be effectively reduced by fermentation, thereby improving the nutritional quality of these cereals and legumes.
Effect of co-fermentation on the functional properties of complementary foods blends from sorghum, pumpkin seed and carrot flour

Table (3) presents the result of the functional properties of the complementary food samples. Generally, bulk density (BD) of flour is the particle mass per unit volume of the container [46]. This important attribute has a direct relationship with the packaging requirement of foods in powdered form [47]. The bulk density of the flour samples ranged from 0.52 to $0.66 \mathrm{~g} / \mathrm{cm}^{-3}$, with the fermented flour samples having significantly $(\mathrm{P}<0.05)$ lower $\mathrm{BD}$ than the unfermented flour. As reported by Singh et al. [47] as fermentation time of a food sample increases, bulk density decreases. Therefore, reduction in bulk density of the fermented flour sample is an advantage to infant foods preparation [48] and Nnam [49] reported that low bulk density of food products gives meal rich in nutrient for both infants and young children, although food products can be excessively eaten leading to high nutrient intake per meal for a baby.

Table-3: Functional properties of complementary food from blends of sorghum, pumpkin seed, and carrot flour

\begin{tabular}{|l|l|l|l|l|}
\hline & Bulk density $\left(\mathbf{g} / \mathbf{c m}^{-3}\right)$ & WAC $(\mathbf{g} / \mathbf{g})$ & OAC $(\mathbf{g} / \mathbf{g})$ & Solubility $(\mathbf{g} / \mathbf{l})$ \\
\hline C A 24 & $0.60^{\mathrm{c}} \pm 0.00$ & $4.02^{\mathrm{a}} \pm 2.11$ & $0.92^{\mathrm{c}} \pm 0.00$ & $4.61 \pm 2.01$ \\
\hline C A 48 & $0.59^{\mathrm{c}} \pm 1.21$ & $4.06^{\mathrm{f}} \pm 0.10$ & $0.88^{\mathrm{d}} \pm 0.11$ & $4.63 \pm 1.11$ \\
\hline C A 72 & $0.56^{\mathrm{d}} \pm 0.11$ & $4.23^{\mathrm{d}} \pm 3.01$ & $0.86^{\mathrm{d}} \pm 2.01$ & $6.03 \pm 0.11$ \\
\hline C B 24 & $0.58^{\mathrm{c}} \pm 0.31$ & $4.11^{\mathrm{e}} \pm 0.11$ & $0.80^{\mathrm{e}} \pm 3.12$ & $5.00 \pm 2.03$ \\
\hline C B 48 & $0.52^{\mathrm{e}} \pm 3.11$ & $4.13^{\mathrm{e}} \pm 1.11$ & $0.74^{\mathrm{f}} \pm 2.30$ & $5.21 \pm 0.02$ \\
\hline C B 72 & $0.54^{\mathrm{e}} \pm 1.01$ & $4.26^{\mathrm{c}} \pm 1.01$ & $0.71^{\mathrm{g}} \pm 0.11$ & $6.31 \pm 0.13$ \\
\hline UC & $0.66^{\mathrm{a}} \pm 0.00$ & $5.00^{\mathrm{a}} \pm 2.01$ & $1.01^{\mathrm{b}} \pm 1.01$ & $4.01 \pm 0.00$ \\
\hline UD & $0.65^{\mathrm{b}} \pm 1.21$ & $4.65^{\mathrm{b}} \pm 2.02$ & $1.81^{\mathrm{a}} \pm 2.00$ & $4.21 \pm 1.40$ \\
\hline
\end{tabular}

Values with different superscript letters within the same column are significantly different $(\mathrm{p}<0.05$, mean $\pm S D, n=3)$ 
The result of the water absorption capacity (WAC) of the flour ranges from 4.02 to $5.00 \mathrm{~g} / \mathrm{g}$. Generally, there was significant $(\mathrm{P}<0.05)$ decrease in the WAC of all the fermented samples. The result agrees with the observation by Sreerama et al. [49] who documented that WAC decrease during fermentation of sorghum flour. Similar trend was reported by Simwaka et al. [49] who revealed reduction in WAC after fermentation of their samples. Water absorption capacity is an important property in preparation of food which influences other functional properties as well as sensory properties of a food [50]. Also, reduction of WAC during fermentations corroborate with the report of Mbata et al. [51] that low WAC and BD are essential in a weaning food to obtain a high energy density food.

The oil absorption capacity of the flour samples decreased significantly $(p<0.05)$ as the fermentation time increase and it ranged from $0.71-$ $1.81 \mathrm{~g} / \mathrm{g}$. This was in agreement with the report of Udensi and Okoronkwo [52] who observed in mucuna bean protein isolate a significant $(\mathrm{p}<0.05)$ decrease in oil absorption capacity after fermentation. The decrease observed could be due to decrease in the food's hydrophilic capacity and increase in fat content during fermentation process.

The solubility of the blended flour samples ranged from 4.01 to $6.03 \mathrm{~g} / \mathrm{l}$. It was observed that WSI increased with fermentation. This was similar to the research done by Simwake et al. [22], they recorded higher WSI in fermented samples. This increase was due to the fermentation process which involves the breakdown of high molecular weight carbohydrate and proteins in the flour samples [53].

Effect of Co-Fermentationon on the Least Gelation Capacity of Complementary Foods Blends From Sorghum, Pumpkin Seed and Carrot

The results of least gelation properties of sorghum, pumpkin seed and carrot are presented in Table 4. Unfermented samples UC and UD formed no gel at 2, 4, 6, 8 and $10 \%$, but formed strong gel at 14 and $16 \%$ while fermented samples formed no gel at 2 , 4 , and $6 \%$, weak gel at 8 and $10 \%$, and formed strong gel at 12,14 and $16 \%$. A stronger gel though weak was formed as the fermentation progresses in days from $8 \%$. Least gelation capacity was shown in the fermented samples than unfermented samples. This was similar to the work done by Msheliza et al. [54] where fermented samples had least gelation capacity than untreated and roasted samples. This could be due to the increase in the concentration [55] which resulted in the rapid change in the consistency of the protein when heat was applied to form a 3-dimensional continuous network which traps and immobilizes the liquid within it to form a rigid structure that is resistant to flow under pressure.

Table-4: Least gelation properties of complementary food from blends of sorghum, pumpkin seed, and carrot flour

\begin{tabular}{|l|c|c|c|c|c|c|c|c|}
\hline & $\mathbf{2 \%}$ & $\mathbf{4 \%}$ & $\mathbf{6 \%}$ & $\mathbf{8 \%}$ & $\mathbf{1 0 \%}$ & $\mathbf{1 2 \%}$ & $\mathbf{1 4 \%}$ & $\mathbf{1 6 \%}$ \\
\hline CA24 & - & - & - & - & \pm & \pm & \pm & \pm \\
\hline CA48 & - & - & - & - & \pm & + & + & + \\
\hline CA72 & - & - & - & \pm & \pm & + & + & + \\
\hline CB24 & - & - & - & - & - & \pm & + & + \\
\hline CB48 & - & - & - & \pm & \pm & + & + & + \\
\hline CB72 & - & - & - & \pm & \pm & + & + & + \\
\hline UC & - & - & - & - & - & \pm & + & + \\
\hline UD & - & - & - & - & - & \pm & + & + \\
\hline
\end{tabular}

\section{Effect of fermentation on the amino acid profile of sorghum, pumpkin seed and carrot flour}

The result of fermentation time on the amino acid profile of sorghum, pumpkin seed and carrot flour blends are presented in Table 5. The result revealed that the amino acid yield followed a trend similar to that of crude protein in Table 1. Fermented flour blends had higher values of amino acid than the unfermented flour blends. The total amino acid increased with fermentation time. The total amino acid progressively increased from $674.3 \mathrm{mg} / \mathrm{g}$ to $711.9 \mathrm{mg} / \mathrm{g}$ for unfermented blends to the maximum levels of 939.4 $\mathrm{mg} / \mathrm{g}$ for the fermented flour blends. This observation was similar to that reported by Apena et al. [56] who reported that fermentation of millet and sorghum for 72 $h$ resulted in increased concentration of some selected amino acid. Inyang et al. [57] similarly reported of increase in essential amino acids in sorghum and cowpea flours that were co-fermented for up to $72 h$. 
Table-5: Amino acid profile of complementary food from blends of sorghum, pumpkin seed and carrot flour

\begin{tabular}{|l|l|l|l|l|l|l|l|l|l|}
\hline S/N & Amino acid mg/g protein & CA 24 & CA 48 & CA 72 & CB 24 & CB 48 & CB 72 & UC & UD \\
\hline 1 & Aspartic acid & 100.2 & 101.0 & 102.5 & 105.4 & 110.1 & 119.5 & 85.4 & 91.2 \\
\hline 2 & Histidine & 22.4 & 25.3 & 27.1 & 28.1 & 28.9 & 32.4 & 19.1 & 20.00 \\
\hline 3 & Isoleucine & 36.5 & 36.0 & 36.7 & 40.0 & 39.1 & 42.5 & 28.4 & 30.4 \\
\hline 4 & Tyrosine & 29.1 & 31.0 & 33.2 & 38.5 & 39.5 & 40.1 & 20.4 & 21.1 \\
\hline 5 & Lysine & 51.3 & 53.4 & 55.1 & 58.3 & 60.0 & 61.1 & 39.2 & 41.4 \\
\hline 6 & Glycine & 35.4 & 37.0 & 37.5 & 38.8 & 39.1 & 39.9 & 31.6 & 33.3 \\
\hline 7 & Methionine & 16.5 & 16.6 & 17.7 & 20.0 & 21.1 & 23.5 & 13.6 & 14.4 \\
\hline 8 & Proline & 27.7 & 28.2 & 29.0 & 30.3 & 30.9 & 30.9 & 22.5 & 24.6 \\
\hline 9 & Arginine & 50.1 & 52.4 & 53.1 & 55.6 & 55.7 & 56.4 & 41.0 & 42.5 \\
\hline 10 & Valine & 31.1 & 33.1 & 33.4 & 36.4 & 38.1 & 40.4 & 25.5 & 27.0 \\
\hline 11 & Glutamic acid & 150.6 & 154.0 & 156.1 & 161.3 & 162.1 & 164.4 & 141.4 & 145.6 \\
\hline 12 & Tryptophan & ND & ND & ND & ND & ND & ND & ND & ND \\
\hline 13 & Alanine & 35.4 & 37.5 & 39.5 & 40.0 & 42.0 & 45.6 & 30.5 & 31.2 \\
\hline 14 & Cysteine & 13.3 & 13.0 & 13.4 & 14.1 & 15.5 & 17.8 & 10.4 & 11.5 \\
\hline 15 & Serine & 40.1 & 42.1 & 42.9 & 44.4 & 48.0 & 48.9 & 35.1 & 36.4 \\
\hline 16 & Threonine & 32.4 & 32.9 & 33.4 & 36.6 & 38.4 & 39.5 & 28.0 & 29.7 \\
\hline 17 & Phenylalanine & 47.7 & 48.1 & 48.8 & 51.5 & 52.2 & 53.4 & 41.1 & 46.6 \\
\hline 18 & Leucine & 77.1 & 77.5 & 78.2 & 80.1 & 82.4 & 82.9 & 61.1 & 65.0 \\
\hline 19 & TAA & 795.9 & 819.1 & 837.6 & 878.4 & 902.9 & 939.4 & 674.3 & 711.9 \\
\hline 20 & TEAA & 334.0 & 341.6 & 349.9 & 375.5 & 386.3 & 401.2 & 267.7 & 287.1 \\
\hline & TEAA/TAA (\%) & 41.97 & 41.70 & 41.77 & 42.75 & 42.78 & 42.71 & 39.7 & 40.33 \\
\hline
\end{tabular}

TTA $=$ Total amino acids, TEAA $=$ Total essential amino acids

Glutamic acid was the highest contributor to the total amino acids and ranged from 141.4 to 164.4 $\mathrm{mg} / \mathrm{g}$ protein followed by aspartic acids which ranged from 85.4 to $119.5 \mathrm{mg} / \mathrm{g}$ protein.

All the samples were high in arginine, which is an essential amino acid required for child's growth. In legume-based food, the limiting amino acids which determine the protein quality are methionine and cysteine [58]. In this present research both methionine and cysteine increased with fermentation from 13.6 to $21.1 \mathrm{mg} / \mathrm{g}$ protein and 10.4 to $17.8 \mathrm{mg} / \mathrm{g}$ protein respectively. According to Mojisola [59], foods low in protein results to protein-energy malnutrition (PEM), therefore, for lecithin formation, methionine is needed in foods. Dietary nitrogen can substitute for amino acid requirement level of protein intake in foods, this is reflected in the amino acid score [60]. According to FAO, WHO and UNU [60], the samples showed adequate protein percentage ratios of total essential amino acids (TEAA) to total amino acids (TAA) within $39 \%$ for infants, $11 \%$ for adults and $26 \%$ for children, respectively [60].
Effect of fermentation time on the carotenoids content of complementary foods from blends of sorghum, pumpkin seed and carrot flour

The result of total carotenoids of unfermented and fermented flour blends are presented in Table 6 . The total carotenoids of unfermented flour blends were higher than that of fermented ranging from 251.5 to $261.5 \mu R E / 100 \mathrm{~g}$ and 205.3 to $239.0 \mu R E / 100 \mathrm{~g}$, respectively. Due to deficiency diseases like infant mortality and night blindness, carotenoids are highly needed for growth and good vision because they are good precursor of vitamin A [61]. Pumpkin is an excellent source of pro-Vit A carotenoids. It was also noted that as fermentation progresses with time, the quantity of carotenoid decreased. Depending on the nature of food sample, factors such as light, $\mathrm{pH}$ and oxygen which takes place during fermentation affects nutritional constituent of foods. Carotenoids are mostly lost through excessive exposure to sunlight and oxygen [62]. This was in agreement with the report of Sulaeman [63], which showed that carotenoid content of a food product was reduced during fermentation. Also, Ahmad [63] reported that fermentation reduced carotenoid content of carrot as revealed in this study. The low carotenoid values can be traced to its thermolabile nature or isomerisation from trans-carotenoids to cis-carotenoids which liberate organic acids at fermentation [64]. It was noted that the carotenoid contents increased as more pumpkin seed was added to the flour blends.

Table-6: Carotenoid content of complementary food from blends of sorghum, pumpkin seed, and carrot flour

\begin{tabular}{|l|l|l|l|l|l|l|l|l|l|}
\hline S/N & Carotenoids (NRE/100g) & CA 24 & CA 48 & CA 72 & CB 24 & CB 48 & CB 72 & UC & UD \\
\hline 1 & & $219.1^{\mathrm{e}}$ & $211.1^{\mathrm{f}}$ & $205.3^{\mathrm{f}}$ & $239.0^{\mathrm{c}}$ & $230.5^{\mathrm{d}}$ & $225.1^{\mathrm{d}}$ & $251.5^{\mathrm{b}}$ & $261.5^{\mathrm{a}}$ \\
& & \pm & \pm & \pm & \pm & \pm & \pm & \pm & \pm \\
& & 17.7 & 10.7 & 3.2 & 1.0 & 2.2 & 2.4 & 7.5 & 4.1 \\
\hline
\end{tabular}

Values with different superscript letters within the same row are significantly different $(\mathrm{p}<0.05$, mean $\pm \mathrm{SD}, \mathrm{n}=3$ ) 
Effect of fermentation on the total viable count, yeast, and mould count of complementary foods blends from sorghum, pumpkin seed and carrot flour

Table 7 shows the result of fermentation time on the microbial load of fermented and unfermented sorghum, pumpkin seed and carrot flour blends. There was increase in Total Viable Count (TVC) up to $48 h$ of fermentation $\left(6.29 \times 10^{3} \mathrm{cfu} / \mathrm{g}\right)$, which decrease at $72 \mathrm{~h}$ of fermentation $\left(5.02 \times 10^{3} \mathrm{cfu} / \mathrm{g}\right)$. A higher TVC was recorded in the co-fermented flour blends than the unfermented flour blends. This same trend of higher yeast and mould count was observed in that of cofermented samples ranging from $\left(1.48 \times 10^{4}\right.$ to $2.02 \times$ $\left.10^{4} \mathrm{cfu} / \mathrm{g}\right)$ and $\left(1.01 \times 10^{3}\right.$ to $\left.1.21 \mathrm{x} \quad 10^{3} \mathrm{cfu} / \mathrm{g}\right)$ respectively.

Table-7: Total viable count, yeast and mould count of complementary food from blends of sorghum, pumpkin seed, and carrot flour

\begin{tabular}{|l|l|l|l|l|l|l|l|l|l|}
\hline S/N & & CA 24 & CA 48 & CA 72 & CB 24 & CB 48 & CB 72 & UC & UD \\
\hline 1 & Total viable count $(\mathrm{cfu} / \mathrm{g})$ & $5.9 \times 10^{3}$ & $6.29 \times 10^{3}$ & $5.02 \times 10^{3}$ & $5.88 \times 105^{3}$ & $7.33 \times 10^{3}$ & $5.80 \times 10^{3}$ & $4.91 \times 10^{3}$ & $4.50 \times 10^{3}$ \\
\hline 2 & Yeast and mould count $(\mathrm{cfu} / \mathrm{g})$ & $1.48 \times 10^{4}$ & $2.00 \times 10^{4}$ & $2.01 \times 10^{4}$ & $1.51 \times 10^{4}$ & $1.66 \times 10^{4}$ & $2.02 \times 10^{4}$ & $1.01 \times 10^{3}$ & $1.21 \times 10^{3}$ \\
\hline
\end{tabular}

Values with different superscript letters within the same column are significantly different $(\mathrm{p}<0.05$, mean $\pm \mathrm{SD}, \mathrm{n}=3$ )

Different microorganisms were isolated during the course of this research Table 8 . They include Lactobacillus reuteri, Lactobacillus fermentum, Lactobacillus plantarum, Saccharomyces cerevisiae, Lactobacillus nantansis, Staphylococcus spp and $S$. aureus. As fermentation progresses, there was increase in TVC, yeast and mould count; this increase might be due to the utilization of the substrates by microorganism. The lactic acid bacteria group and the yeast Saccharomyces cerevisiae were the predominant micro-organisms isolated from the fermentation medium which shows the dominating ability of the starter organisms towards substrates. A report according to Olukoya et al. [65] described the lactic acid bacteria as the dominant organisms in cereal fermentation. The microorganisms isolated from this study were similar to those reported by Ogodo et al. [66] and Ekwem et al. [67].

Table-8: Microorganism isolated from the fermentation of sorghum, pumpkin seed and carrot flour blends

\begin{tabular}{|l|l|l|l|l|l|l|l|l|}
\hline & CA24 & CA 48 & CA 72 & CB 24 & CB 48 & CB 72 & UC & UD \\
\hline Staphylococcus spp & $\mathrm{P}$ & $\mathrm{P}$ & $\mathrm{P}$ & $\mathrm{P}$ & $\mathrm{P}$ & $\mathrm{P}$ & $\mathrm{P}$ & $\mathrm{P}$ \\
\hline Lactobacillus nanterisis & $\mathrm{P}$ & $\mathrm{P}$ & $\mathrm{P}$ & $\mathrm{P}$ & $\mathrm{P}$ & $\mathrm{P}$ & - & $\mathrm{P}$ \\
\hline S aureus & $\mathrm{P}$ & $\mathrm{P}$ & $\mathrm{P}$ & $\mathrm{P}$ & $\mathrm{P}$ & $\mathrm{P}$ & $\mathrm{P}$ & $\mathrm{P}$ \\
\hline Lactobacillus reuteri & $\mathrm{P}$ & $\mathrm{P}$ & $\mathrm{P}$ & $\mathrm{P}$ & $\mathrm{P}$ & - & - & $\mathrm{P}$ \\
\hline Lactobacillus fermentum & $\mathrm{P}$ & - & $\mathrm{P}$ & $\mathrm{P}$ & $\mathrm{P}$ & $\mathrm{P}$ & - & $\mathrm{P}$ \\
\hline Lactobacillus plantarum & $\mathrm{P}$ & $\mathrm{P}$ & $\mathrm{P}$ & - & - & $\mathrm{P}$ & - & $\mathrm{P}$ \\
\hline Saccharomyces cerevisiae & $\mathrm{P}$ & $\mathrm{P}$ & $\mathrm{P}$ & $\mathrm{P}$ & $\mathrm{P}$ & $\mathrm{P}$ & $\mathrm{P}$ & $\mathrm{P}$ \\
\hline
\end{tabular}

Effect of co-fermentation on the sensory properties of complementary foods blends from sorghum, pumpkin seed and carrot flour

The result of fermentation time on the sensory properties of complementary food prepared from sorghum, pumpkin seed and carrot are presented in Fig. 1. There was no significant $(\mathrm{P}>0.05)$ difference in the consistency of the fermented samples, with the scores ranging from 8 to 8.6 , which were higher than the unfermented samples. The unfermented samples scored significantly $(\mathrm{P}<0.05)$ lower (below 7.0$)$ in taste and aroma than the fermented sample, with the unfermented samples scoring below 7.0. Offia et al. [8] evaluated the sensory properties of cereal/legume mixtures as complementary food and reported a score higher than 7.0 in fermented samples.

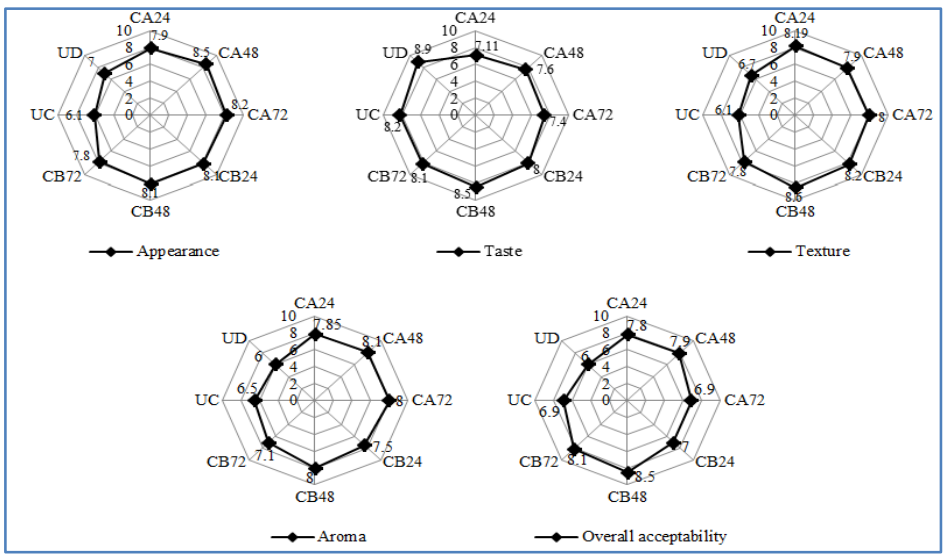

Fig-1: Sensory analysis of porridges from malted and pre-gelatinized maize, soy and carrot blend 
For consistency, all the samples were liked very much, with the highest mean score of 8.5 for sample CB 48. The best in overall acceptability was sample CB 48, which was liked very much. The sensory parameters results revealed that mothers prefer the cofermented sample to unfermented sample in terms of overall acceptability.

\section{CONCLUSION}

Combination of locally available food can be used as home-based complementary foods. The study has shown that nutrient composition of fermented sorghum, pumpkin seed and carrot flour blends varied with co-fermentation times. Co-fermentation decreased the antinutrient properties of the complementary foods, hence improved the nutritional composition of the blends. $\beta$-carotenoid level increased more in cofermented flour blends than the unfermented flour blends. And also fermentation improved the functional properties of the weaning food blends produced. Total viable counts decreased as fermentation progressed to $72 h$, but yeast and moulds were increased with progressive increase in time of fermentation, so care should be taken to reduce the increase of these microorganisms. The sensory parameters results revealed that mothers prefer the co-fermented sample to unfermented sample in terms of overall acceptability. Co-fermentation presents an easily adaptable, costeffective, and time-saving preparation method for mothers to make better use of their locally available food resources, without adversely affecting the quality attributes of the product. Therefore, the domestic processing method like fermentation is recommended to improve the nutritional status of infants in the developing countries.

\section{REFERENCES}

1. Black, R. E., Allen, L. H., Bhutta, Z. A., Caulfield, L. E., De Onis, M., Ezzati, M., \& Group, C. U. S. (2008). Maternal and child undernutrition: Global and regional exposures and health consequences. The Lancet, 371(9608), 243-260.

2. Pelletier, D. L. \& Frongillo, E. A. (2003). Changes in child survival are strongly associated with changes in malnutrition in developing countries. The Journal of Nutrition, 133(1), 107-119.

3. Kinyoki, D. K., Kandala, N.B., Manda, S. O., Krainski, E. T., Fuglstad, G.-A., Moloney, G. M., \& Noor, A. M. (2016). Assessing comorbidity and correlates of wasting and stunting among children in Somalia using cross-sectional household surveys: 2007 to 2010. BMJ Open, 6(3), e009854.

4. WHO (2009). Proceedings of the WHO UNICEF WFP UNHCR informal consultation on the management of moderate malnutrition in fewer than 5 children. Food and Nutrition Bulletin, 30(3), $5464-474$.
5. Dewey, K. G. (2001). Nutrition, growth, and complementary feeding of the breastfed infant. Pediatric Clinics of North America, 48(1), 87-104.

6. Igah, S. (2008). Target food sources for formulating complementary/supplementary foods for weaning purposes. Bayero Journal of Pure and Applied Sciences, 1(1), 20-24.

7. Shamin, A., Mawla, M., Islam, Z., \& Rahman, M. (2003). Palmyra palm-an under exploited carotenerich fruit. Sight Life Newsletter, 2, 21-24.

8. Offiah, V.O., Abu, J.O., \& Yusufu, M.I. (2018). Effect of co-fermentation on functional and pasting properties of maize (zea mays) and soy bean (glycine max) complementary floors. Nigerian Journal of Nutritional Sciences, 39(1), $63-69$.

9. Oyarekua, M. A. (2012). Effect of germination, boiling and co-fermentation on the viscosity of maize/cowpea mixture as complementary infant food. American Journal of Food Technology, 7, 112.

10. Oluwole, O. B., Kosoko, S. B., \& Owolabi, S. O. (2012). Development and production of high protein and energy density beverages from blends of maize (Zea mays), Sorghum (Sorghum bicolor) and Soybeans (Glycine max) for school aged children: Effect of malting period on chosen proximate parameters and sensory qualities of developed beverages. International Journal of Applied Science and Technology, 2(7), 285-292.

11. Nyachoti, C., Atkinson, J., Leeson, S. 1997. Sorghum tannins: A review. World's Poultry Science Journal, 53(1), 5-21.

12. Gourichon, H. (2013). Analysis of incentives and disincentives for sorghum in Nigeria. Technical Notes Series. Rome: MAFAP, FAO.

13. Nwakalor, C. N., \& Obi, C. D. (2014). Formulation and sensory evaluation of sorghum based weaning food fortified with soybean and unripe plantain flour. International Journal of Nutrition and Food Sciences, 3(5), 387-390.

14. Tizazu, S., Urga, K., Belay, A., Abuye, C., \& Retta, N. (2011). Effect of germination on mineral bioavailability of sorghum-based complementary foods. African Journal of Food, Agriculture, Nutrition and Development, 11(5), 5083-5095.

15. FAO/WHO (2001). Human vitamin and mineral requirements. Report of a Joint FAO/WHO expert consultation, Bangkok, Thailand. Rome: Food and Nutrition Division, FAO, Rome.

16. Naves, L. P., Corrêa, A. D., Santos, C. D., Natividade, M. A. E., \& Abreu, C. M. P. (2010). Nutrientes e propriedades funcionais em sementes de abóbora (Cucurbita maxima) submetidas a diferentes processamentos. Ciência e Tecnologia de Alimentos, 30(Supl 1), 185-190.

17. Nkosi, C., Opoku, A., \& Terblanche, S. (2006). Antioxidative effects of pumpkin seed (Cucurbita pepo) protein isolate in CCl4-Induced liver injury 
in low-protein fed rats. Phytotherapy Research, 20(11), 935-940.

18. Dhiman. (2009). African cucurbita pepo, properties of seed and variability in salty and composition of seed oil. Journal of Phytochemistry, 54, $71-75$.

19. Maziya-Dixon, B., Akinyele, I.O., Oguntona, E.B., Nokoe, S., Sanusi, R.A., \& Harris, E. (2004). Nigerian Food Consumption and Nutrition Survey, $2001 \quad 2003 . \quad$ Ibadan: IITA/USAID/UNICEF/USFDA.

20. Obinna-Echem, P., Barber, L., \& Enyi, C. (2018). Proximate composition and sensory properties of complementary food formulated from malted pregelatinized maize, soybean and carrot flours. Journal of Food Research, 7(2), 17-24.

21. Joao, C.S.D. (2014). Nutritional and Health Benefits of Carrots and their seed extracts. Food and Nutrition Sciences, 5, 2147 - 2156.

22. Simwaka, J.E., Chamba, M.V.M., Huiming, Z., Masamba, K.G., \& Luo, Y. (2017). Effect of fermentation on physiochemical and antinutritional factors of complementary food from millet, sorghum, pumpkin and amaranth seed flours. International Food Research Journal, 24(5), $1869-1879$.

23. Usha, A., \& Chandra, T.S. (1998). Anti-nutrient Reduction and Enhancement in Protein, starch, and mineral availability in fermented flour of finger millet (Eleusine Coracana). Journal of Agricultural and Food Chemistry, 46(7), $2578-2582$.

24. AOAC. (2000). Official methods of analysis of AOAC International. 17th edn. USA: AOAC International, Gaithersburg, Maryland.

25. Joshi, A. U., Liu, C., \& Sathe, S. K. (2015). Functional properties of select seed flours. LWTFood Science and Technology, 60(1), 325-331.

26. AOAC. (2005). Official methods of analysis of the Association of Official Analytical Chemists. 17th edn. USA: VA.

27. Anderson, R.A., Conway, H.F., Pfeifer, P.F.A., \& Griffin, E.L. Jr. (1969). Gelatinization of corn grits by roll and extrusion cooking. Cereal Science Today, 14, $4-12$.

28. Sathe, S., Ponte, J., Rangnekar, P., \& Salunkhe, D. (1981). Effects of addition of great northern bean flour and protein concentrate on rheological properties of dough and baking quality of bread. Cereal Chemistry, 58(2), 97-100.

29. Leach, H. W., McCowen, L. D., \& Schoch, T. J. (1959). Structure of starch granule. I. Swelling and solubility patterns of various starches. Cereal Chemistry, 36, 534-544.

30. Price, M. L., Van Scoyoc, S., Butler, L. G. (1978). A critical evaluation of the vanillin reaction as an assay for tannin in sorghum grain. Journal of Agricultural and Food Chemistry, 26(5), 12141218.

31. Haug, W., \& Lantzsch, H. J. (1983). Sensitive method for the rapid determination of phytate in cereals and cereal products. Journal of the Science of Food and Agriculture, 34(12), 1423-1426.

32. Onyango, C., Noetzold, H., Ziems, A., Hofmann, T., Bley, T., \& Henle, T. (2005). Digestibility and antinutrient properties of acidified and extruded maize-finger millet blend in the production of ogi. LWT-Food Science and Technology, 38(7), 697 707.

33. Rodriguez-Amaya, D. B., \& Kimura, M. (2004). Harvest plus handbook for carotenoid analysis (Vol. 2). Citeseer.

34. Oyarekua, M. A. (2009). Co-fermentation of cassava/cowpea/carrot to produce infant complementary food of improved nutritive quality. Asian Journal of Clinical Nutrition, 1(3), 120-130.

35. Ihekoronye, A. I., \& Ngoddy, P. O. (1985). Integrated food science and technology for the tropics. Ibadan: Macmillan.

36. FAO/WHO (1991). CODEX CAC/GL 08. 1991. Codex alimentarius: Guidelines on formulated supplementary foods for older infants and young children. Vol. 4. New York: FAO/WHO Joint Publications.

37. Pranoto, Y., Anggrahini, S., \& Efendi, Z. (2013). Effect of natural and lactobacillus plantarum fermentation on in-vitro protein and starch digestibilities of sorghum flour. Food Bioscience, 2, 46-52.

38. Chakraverty, A. (2004). Post-harvest of oil seeds. New Delhi: Oxford Publishing Company, Private Limited.

39. Mbata, T. I., Ikenebomeh, M. J. \& Ezeibe, S. (2009). Evaluation of mineral content and functional properties of fermented maize (Generic and specific) flour blended with bambara groundnut (Vigna subterranean L). African Journal of Food Science, 3(4), 107-112.

40. Afify, A.E.M.M., El-Beltagi, H.S., El-Salam, S.M.A., \& Omran, A.A. (2012). Effect of soaking, cooking, germination and fermentation processing on proximate analysis and mineral content of three white sorghum varieties (Sorghum bicolor L. Moench). Notulae Botanicae Horti Agrobotanici Cluj-Napoca, 40(2), 92-98.

41. Obizoba, I. C. \& Amaechi, N. A. (1993). The effect of processing methods on the chemical composition of baobab (Adansonia digitata. L) Pulp and seed. Ecology of Food and Nutrition, 29, 199-205.

42. Nnam, N, M. (1995). Evaluation of the nutritional quality of fermented cowpea (vigna unguiculata) flours. Ecology of Food and Nutrition, 33, 273279.

43. Onweluzo, J., \& Nwabugwu, C. (2009). Fermentation of millet (Pennisetum americanum) and pigeon pea (Cajanus cajan) seeds for flour production: Effects on composition and selected functional properties. Pakistan Journal of Nutrition, $8(6), 737-744$. 
44. Obizoba, I.C. \& Atti, J.V. (1991). Effect of soaking, sprouting and fermentation on the nutritional quality of bambara nut (Vaandzeia substerranean L Thauars) and its product (Milk). Plant Foods for Human Nutrition, 42, 13- 23.

45. Adeyemo, S., \& Onilude, A. (2013). Enzymatic reduction of anti-nutritional factors in fermenting soybeans by Lactobacillus plantarum isolates from fermenting cereals. Nigerian Food Journal, 31(2), 84-90.

46. Barbosa-Canovas, G., \& Yan, H. (2012). Powder characteristics of preprocessed cereal flours Characterization of cereals and flours. CRC Press.

47. Singh, A., Yadav, N., \& Sharman, S. (2012). Effect of fermentation on physiochemical properties and in vitro starch and protein digestibility of selected cereals. International Journal of African Food Science, 2, 66-70.

48. Onimawo, I., \& Egbekun, K. (1998). Comprehensive food science and nutrition. Revised Edition. Benin City: Ambik Publishers.

49. Nnam, N. M. (2000). Chemical evaluation of multimixes formulated from some local staples for use as complementary foods in Nigeria. Plant Foods for Human Nutrition, 55, 255-263.

50. Sreerama, Y. N., Sashikala, V. B., Pratape, V. M., \& Singh, V. (2012). Nutrients and antinutrients in cowpea and horse gram flours in comparison to chickpea flour: Evaluation of their flour functionality. Food Chemistry, 131(2), 462-468.

51. Mbata, T., Ikenebomeh, M. J., \& Alaneme, J. (2009). Studies on the microbiological, nutrient composition and antinutritional contents of fermented maize flour fortified with bambara groundnut (Vigna subterranean L). African Journal of Food Science, 3(6), 165-171.

52. Udensi, E. A., \& Okoronkwo, K. A. (2006). Effects of fermentation and germination on the physicochemical properties of Mucuna cochinchinensi protein isolate. African Journal of Biotechnology, 5(10), 896-900.

53. Amadi, E., Barimalaa, I., \& Omosigho, J. (1999). Influence of temperature on the fermentation of bambara groundnut (Vigna subterranea) to produce a dawadawa-type product. Plant Foods for Human Nutrition, 54(1), 13-20.

54. Msheliza, E., Hussein, J., Ilesanmi, J., \& Nkama, I. (2018). Effect of fermentation and roasting on the physicochemical properties of weaning food produced from blends of sorghum and soybean. Journal of Nutrition and Food Science, 8(681), 2.

55. Iwe, M.O. (2003). The Science and Technology of Soy Bean. Enugu: Rojoint Communication Services Limited.
56. Apena, A., Opeolu, S., Bamidele, F., \& Shittu, A. (2015). Nutrient changes during fermentation of some selected cereals. Sky Journals of Biochemistry Research, 4(2), 010-012.

57. Inyang, U.E., Umoh, H.I., \& Ukwo, S.P. (2019). Effect of Co-fermentation Duration on the nutritional composition and Anti-nutritional contents of sorghum-cowpea flour and sensory properties of their Gruels. IOSR Journal of Environmental Science, Toxicology and Food Technology, 13(2), 56-64.

58. Shurtleff, W., \& Aoyagi, A. (1979). The book of tempeh (Vol. 1). Soyinfo Center.

59. Mojisola A.O. (2009). Co-fermentation of Cassava/Cowpea/carrot to produce infant complementary food of improved nutritive quality. Asian Journal of Clinical Nutrition, 1(3), 120-130.

60. FAO/WHO/UNU. (1985). Energy and protein requirements. Reports of a Joint FAO/WHO/UNU Expert Consultations. Technical Report Series 724. Geneva: World Health Organization.

61. Rodriguez-Amaya, D. B. (1999). Latin American food sources of carotenoids. Archivos Latinoamericanos de Nutricion, 49(3 Suppl 1), 7484.

62. Rodriguez-Amaya, D. (2002). Effects of processing and storage on food carotenoids. Sight and Life Newsletter, 3, 25-35.

63. Sulaeman, A. (2001). Development and evaluation of deep -fried carrot chips as a source of vitamin A. ETD collection for University of NebraskaLincoln. AAI3034392. Retrieved August 12, 2019 from https://digitalcommons.unl.edu/dissertations/AAI3 034392.

64. Della, B., \& Rodriguez-Amaya. (2009). Effect of processing and storage on food carotenoid. Sight and life Newsletter 3/2002 www.mostproject.org/PDF/30\%202002\%20SLpdf.

65. Olukoya, D., Ebigwei, S., Olasupo, N., \& Ogunjimi, A. (1994). Production of dogik: An improved Ogi (Nigerian fermented weaning food) with potentials for use in diarrhoea control. Journal of Tropical Pediatrics, 40(2), 108-113.

66. Ogodo, A. C., Ugbogu, O. C., Onyeagba, R. A., \& Okereke, H. C. (2019). Microbiological quality, proximate composition and in vitro starch/protein digestibility of Sorghum bicolor flour fermented with lactic acid bacteria consortia. Chemical and Biological Technologies in Agriculture, 6(1), 7.

67. Ekwem, O.H., \& Okolo, B.N. (2017). Microorganisms isolated during fermentation of sorghum for production of Akamu (A Nigerian fermented Gruel). Microbiology Research Journal International, 21(4), 1-5. 